\title{
TRANSMISSION OF SOUND THROUGH WALL AND FLOOR STRUCTURES
}

\author{
By V. L. Chrisler and W. F. Snyder
}

\section{ABSTRACT}

This paper contains a report of the work on sound transmission through (1) a large number of masonry walls and floors and other materials which are homogeneous in construction, the results showing that weight is the most important factor under these conditions; (2) a few compound walls and floors which have a masonry core, and (3) a few stud walls.

The results are given for five frequency bands covering a range from 250 to 3,365 cycles per second. Transmission tests were also made for impact noises. Specifications for the construction of the various panels used are appended.

\section{CONTENTS}

I. Introduction

II. Methods of measurement_._._. 542

III. Method of expressing results (sensation units)

IV. Discussion of results _... 543

1. Air-borne sounds................. 543

2. Impact or tapping sounds _._. 550

3. General conclusions.

V. Description of panels. 553

VI. General specifications for construction of test panels._._. 556

\section{INTRODUCTION}

In several previous publications of the Bureau of Standards ${ }^{1}$ there is to be found a description of the methods employed in the bureau's laboratories for determining the sound transmission of various types of wall, floor, and ceiling construction, with a statement of the results obtained on a number of test panels of different types. The present paper gives additional results which have been obtained since the issue of the last publication in June, 1927. The methods employed in this later work have been substantially those described in the earlier publications. The only change of importance has been an improvement in the source of alternating current used to produce sound. This is described in a later place in the present paper.

In the modern apartment house, office building, hotel, and other buildings of this nature sound insulation is becoming of increasing

1 Transmission and Absorption of Sound by Some Building Materials, B. S. Sci. Paper No. 526. Soundproofing of Apartment Houses, B. S. Tech. Paper No. 337. Transmission of Sound through Building Materials, B. S. Sci. Paper No. 552. 
importance. This consideration is often difficult to satisfy simultaneously with other important requirements. The rising costs of construction have brought about a tendency to make nonload-bearing walls as thin as possible, and, due to requirements which are necessary to eliminate the fire hazard, the modern fireproof building is liable to be noisy, as sound is easily transferred along steel beams or through thin masonry walls. The problem is to find a type of wall which will have maximum opacity to sound with minimum weight and with a reasonable cost of construction.

To meet this situation, the Bureau of Standards, with the cooperation of a number of manufacturers of building materials, has undertaken an extensive program in which the sound-insulating properties of a large number of structures have been measured in the laboratory. This work has not been confined to heavy partition walls but has been extended to lighter types and to various materials which might be used in such structures. The lightest material used was wrapping paper, while the heaviest structure was a combination tile floor with a cinder fill and concrete finish, weighing 109 pounds to the square foot.

Some of the most interesting results have been obtained with the use of the lighter materials, such as are employed in the construction of airplane cabins. In the study of this aspect of the general problem it has become apparent that some of the conclusions reached in considering heavier building structures do not apply to combinations of lighter material.

\section{METHODS OF MEASUREMENT}

In much of the work described in the present paper an improved source of alternating current has been used, in the form of a beatfrequency oscillator. As such instruments have lately come on the market, it may be sufficient to give a brief description of the type employed. It contained two circuits, each of radio-frequency. One of these circuits was maintained by means of a piezoelectric crystal of quartz, while the capacity of the other was varied to give beats of the desired audio-frequencies. The width of the frequency bands was controlled by the use of a revolving condenser of suitable capacity, similar to that described in Scientific Paper No. 526.

By means of this apparatus it has been found possible to make measurements at lower frequencies than with the oscillator formerly used. In addition, the frequency band could be made wider at the lower frequencies. A number of measurements made on a series of panels, using both oscillators, showed that the mean reduction factor was not appreciably affected by the width of the band. 


\section{METHOD OF EXPRESSING RESULTS (SENSATION UNITS)}

All results given in this paper and in the previous publications above referred to have been obtained by the use of the telephone receiver as a detector and measurer of sound energy. The indications of this instrument are given on what is called the physical scale, which measures the energy of the sound wave. But the instrument most universally used for detecting sound and estimating its intensity is the human ear, and unfortunately the ear does not respond according to the physical scale. As the intensity of a sound increases steadily on the physical scale, the response of the ear fails to keep pace with it. There appears to be in the ear a regulating or protective mechanism whose nature is not understood, which, like the wellknown mechanism of the eye, protects the organ against excessive stimulation. Experiment shows that the response of the ear is proportional to the logarithm of the physical intensity; that is, energies proportional to 10,100 , and 1,000 would produce in the ear effects proportional to 1,2 , and 3 , respectively. This logarithmic scale has been termed in previous papers the ear scale and has been used for expressing results because of its natural fitness.

A slight modification of this scale has been employed for some time by telephone engineers ${ }^{2}$ and is used in all audiometers made by the Western Electric Co. This scale merely multiplies the numbers of the ear scale by 10 , the unit of this new scale being that fractional change in intensity which is approximately the smallest that the average ear can detect. For this reason this unit is called a sensation unit. In the example given above, intensities corresponding to 1,2 , and 3 on the ear scale would be represented by 10,20 , and 30 sensation units.

It seems advisable that the same units should be used by all engaged in acoustic work, and consequently sensation units have been adopted in this paper. Reduction factors given on the ear scale in previous publications may be converted into sensation units by multiplying by 10 .

Wallace Waterfall, in a private communication, has suggested a way of illustrating the values of sensation units in familiar terms. We may call it an ear sensation scale. (Fig. 1.)

\section{DISCUSSION OF RESULTS}

\section{AIR-BORNE SOUNDS}

The present paper gives the results of experiments on the sound transmission of over 70 panels, ranging in weight from a masonry structure of 109 pounds per square foot down to a single thickness of

${ }^{2}$ Fletcher, Bell Telephone Laboratories, Reprint B-152-1; J. Frank. Inst.; September, 1923. 
wrapping paper. The results for the principal cases are given graphically in Figure 2, plotting the reduction factor in sensation units against the logarithm of the weight per square foot. The numerical values for all the panels are given in Table 1 .

In general, it appears that for panels which are more or less homogeneous in structure the points lie close to a straight line; that is, mass is the predominating factor, but it is quite apparent that mass is not always the only factor in the case. Where the panel departs

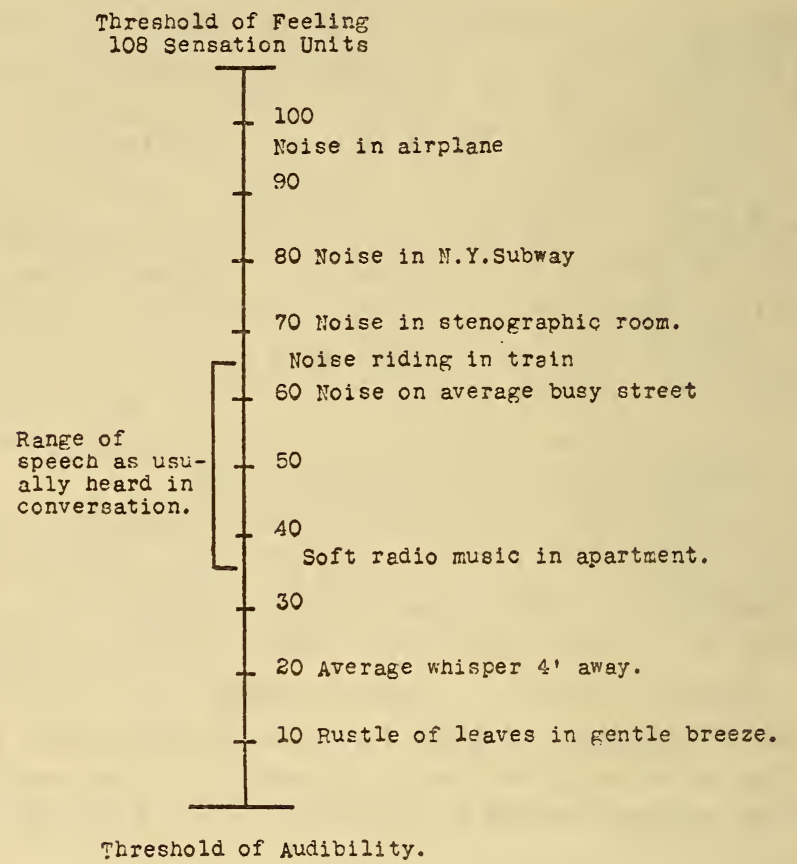

FIG. 1.-Ear sensation scale

from homogeneity, as in panels 77 and $78 \mathrm{~b}$, structure becomes of importance.

As stated in a previous paper, ${ }^{3}$ a partition wall or floor acts in much the same manner as a large diaphragm. It is well known that the amplitude of vibration of a large diaphragm depends upon its mass, stiffness, and damping factor.

Consider panels 79,80 , and 81 . These panels differed but slightly in weight, yet No. 79 transmitted quite a little more sound than either No. 80 or No. 81 . The principal difference was that the workmanship was not as good in No. 79. The bricks of No. 79 were not as well embedded in the mortar as in the other two, and the vertical joints were not filled. According to McBurney, ${ }^{4}$ a panel built like

3 B. S. Sci. Paper No. 552.

4 J. W. McBurney, Effect of Workmanship on Strength of Brick Masonry, Am. Architect, 132, p. 613; Nov. 5, 1927. 
No. 80 has from 24 to 112 per cent greater wall strength than No. 79 . It would appear that this same factor affects the sound transmission to some extent.

Consider floor panels No. 78a and 78b. Panel 78a was a better sound insulator than $78 \mathrm{~b}$ and yet was considerably lighter. When these measurements were first taken, it seemed probable that some error had been made in the measurements. To verify these results, a second set of measurements was made on No. $78 \mathrm{~b}$, with a result exactly the same as before. The concrete finish and cinder fill were then stripped off, leaving the panel in its original condition as No. 78a. The sound-transmission measurements were then repeated, and the average reduction factor found was within 0.7 sensation unit of its original value. This, again, illustrates that simply loading a panel does not necessarily make it a better sound insulator. The cinder fill had almost no mechanical strength and probably increased the rigidity of the panel very little, but it did form an intimate contact between the slab and concrete finish, so that any vibration of the slab was easily transmitted to the finished part of the floor and hence to the receiving room.

Also consider panels 27 and 28 (B. S. Sci. Paper No. 526) and panels 25, 26, 29, and 30 (B. S. Sci. Paper No. 552). These were panels built of clay tile, gypsum tile, and brick. In each case two panels were built as nearly alike as possible, one being finished with gypsum plaster and the other with lime plaster; and in each case the panels finished with gypsum plaster were slightly better sound insulators than those with lime plaster. It should be emphasized that the difference was not enough to be of any practical importance but merely sufficient to be detected in the laboratory.

There were two other interesting panels among the small ones. These were panels 110 and 111 , consisting of $1 / 8$ and $\frac{1}{16}$ inch sheet lead, respectively. Plotting the results for these panels with those for other materials (fig. 2) it will be seen that the points for these panels fall below the curve, indicating that they transmit more sound than a piece of sheet iron or glass of the same weight.

In every case mentioned in the four preceding paragraphs it is to be noticed that the panel which transmits the least sound is the most rigid.

With the small panels where the material was thin it has been found that the method of holding the edges affects the result. If the clamped area extends in from the edge for about 2 inches, the material transmits less sound than when held only by a narrow rim at the edge. This change in transmission is rather too large to be accounted for by such stiffening as might be produced by clamping for 2 inches around the edge. Further work is being done to determine to what extent the boundary conditions will affect the results. 
From the above it is evident that the result for sound transmission of various materials is not dependent entirely on the mass, though this

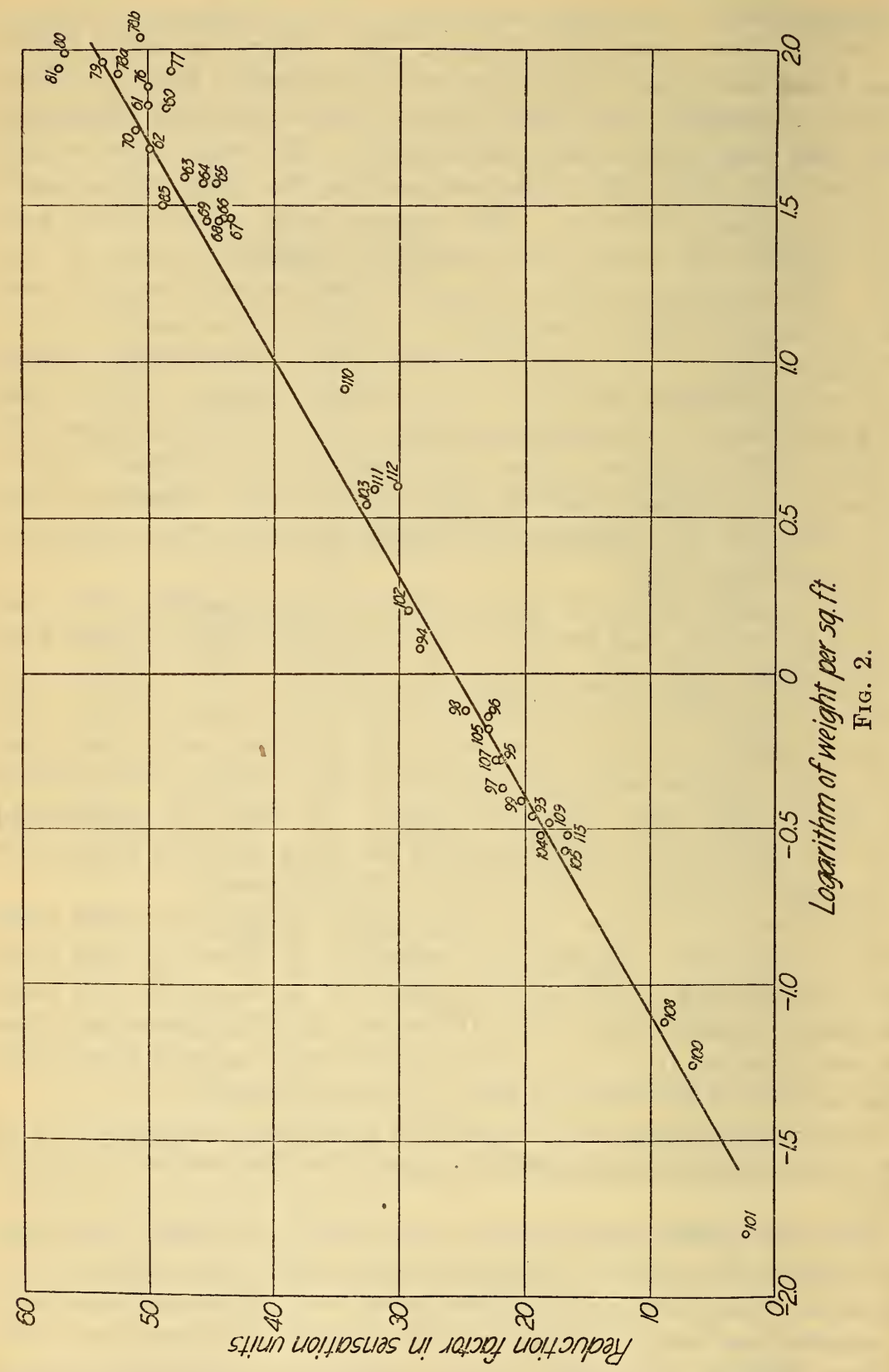

is the most important factor. Figure 2 shows that most structures which are more or less homogeneous do have a reduction factor in sensation units which is nearly proportional to the logarithm of the 
weight per unit area. From this curve the approximate reduction factor of many new structures may be predicted with a reasonable degree of certainty, provided they are tested under similar conditions. If the conditions of test are radically altered, entirely different results may be expected. To illustrate this, the curves in Figure 3 have been plotted, giving results as determined by Sabine, ${ }^{5}$ Heimburger, ${ }^{6}$ and the Bureau of Standards. The reduction factors as given by each observer are not directly comparable, as the methods by which they are measured are entirely different. For instance, Sabine makes all of his measurements by the reverberation method, using a small receiving room in which the observer stands with his ear close to the panel. This makes the reduction factor less than it would be if the

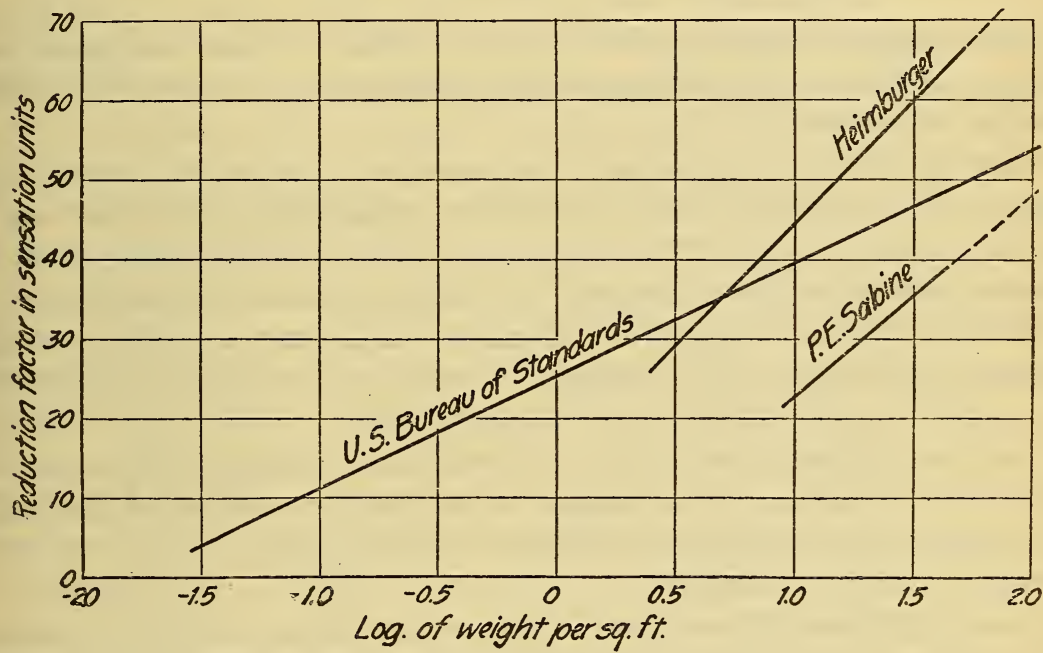

FIG. 3.-Comparative results at various laboratories on sound transmission of panels

receiving room were larger and the observer stood at some distance from the panel. Heimburger places a loud-speaker horn close to the panel and surrounds it by a box so that in all probability not more than 4 or 5 square feet of wall surface are appreciably affected by the sound waves. For walls with a thickness of 6 to 8 inches the thickness of the wall becomes comparable to the surface area affected, and the wall acts as if it were much stiffer than if a larger section were used. This increases the reduction factor.

Each method has its advantages, and while the different methods do not give the same absolute results they should agree in the comparison of a number of different panels. The fact that the results depend upon the method, and also the room in which the measurements are made, is unfortunate. The art of measuring sound trans-

${ }^{5}$ Paul E. Sabine, The Armour Eng.; May, 1926.

- Gunnar Heimburger, the Am. Architect; Jan. 20, 1928. 
mission is not yet on as definite a basis as the measurement of heat conductivity. In consequence, each observer must in some way explain what is meant by the figures which he gives for the reduction factor. Referring to Figure 3 and comparing the ordinates in sensation units for the same abscissas, we obtain the following values from the curves given by the three different observers.

\section{Reduction factor in sensation units}

\begin{tabular}{|c|c|c|}
\hline $\begin{array}{c}\text { Bureau of } \\
\text { Standards }\end{array}$ & Sabine & $\begin{array}{c}\text { Heim- } \\
\text { burger }\end{array}$ \\
\cline { 2 - 3 } 32.4 & & 29.0 \\
39.5 & 22.7 & 44.5 \\
44.2 & 31.0 & 54.7 \\
49.0 & 39.5 & 65.0 \\
53.7 & 48.0 & 75.2 \\
\hline
\end{tabular}

The numerical values of the reduction factor in sensation units for results obtained at the Bureau of Standards may be classified in four groups, as follows:

Panels Whose Reduction Factors are Over 60 Sensation UNITS.-Conversation carried on in an ordinary tone of voice is reduced to inaudibility. If there is external noise in the listening room, a shout on the other side of the panel would be practically unnoticeable.

Panels Whose Reduction Factors Lie Between 50 and 60 Sensation Units.-Conversation in ordinary tones heard through the panel is barely audible but unintelligible.

Panels Whose Reduction Factors Lie Between 40 and 50 Sensation Units.-Conversation in ordinary tones heard through the panel is quite audible but difficult to understand. If the voice is raised, it becomes intelligible.

Panels Whose Reduction Factors are Less than 40 SensaTION UNITS.-Conversation in ordinary tones heard through the panel is distinctly audible and intelligible.

The above comparisons are based on tests in a listening room in which there was no noise and which was quite reverberant. In a room furnished with rugs, draperies, or other sound-absorbing objects the panels would be apparently more effective than when tested in bare rooms.

A practical demonstration of the above statement was made by lining a large box with highly absorbing material. The average reduction factor of this box was slightly under 40 sensation units. The box was placed in a very reverberant room. A person inside the box could understand everything said by a person outside, while the person outside was unable to understand a single word that was spoken by the person inside unless he raised his voice The reason for this was that the absorbing material in the box lowered the intensity of sound originating within to such an extent that it was no longer sufficient to carry through and be audible after transmission. 
For sound generated outside in a reverberant room there was no absorbing material, and in consequence the sound could build up to an intensity level sufficient to carry it through to the person inside the box. In certain cases this principle may be of practical value. If a room contains a number of typewriters, a partition might be built which is insufficient to prevent the sound reaching the other side if the typewriting room is reverberant, but if absorbing material in sufficient quantity be added to the walls of the typewriting room the partition might be satisfactory. The absorbing material in this case would serve two purposes-it would reduce the noise level so that it would be much pleasanter for the operators of the machines; and, due to the reduced noise level, a lighter partition would be sufficient to confine the sound to the room of its origin.

Attention must be called to the masking effect of external noise. If a panel having a reduction factor between 30 and 40 sensation units is taken as an example, the following facts may be noticed. If there is no external noise and the panel acts as the wall between two rooms which are fairly reverberant, it is quite easy for two people who are on opposite sides of the panel to carry on a conversation; but if there is the slightest noise in the room where the person is listening, the conversation becomes a mumble, and the chances are that not a single word will be understood. The louder the noise the greater the masking effect.

From the above it is readily seen that a panel might give entirely satisfactory results under some conditions while under other conditions it would be entirely unsatisfactory. In other words, the conditions under which a structure is to be used are to be considered, as a given structure may seem satisfactory or unsatisfactory as these conditions are favorable or unfavorable.

Returning to the results which were obtained for masonry walls, one fact is at once evident-that for solid masonry a wall to be a good sound insulator must be excessively heavy. In the search for a type of structure which would give more efficient insulation it was found that the insulation was materially increased if the wall were split into layers. For masonry walls it was found that this could be accomplished by using wood furring strips to which was fastened the plaster base and finally the plaster coat. With 4-inch clay tile furred out in this manner on both sides, the sound insulation was, perhaps, a little better than that of an 8-inch brick wall without furring. It should also be noticed that the nature of the plaster base makes little difference, as the results were about the same for metal lath, masonite, and insulite.

Tests were also made to determine whether a change in the method of attaching the furring would make any material difference. In $25326^{\circ}-29-2$ 
panel No. 82 the furring strips were wired to the brickwork by wires laid in the mortar when the panel was built. The furring strips thus attached were not perfectly tight at best but could be moved, perhaps, a few hundredths of an inch. Panel No. 83 had the same brick center as No. 82 , but the plaster and furring strips were taken off, holes drilled into the brick, and nailing plugs driven into the holes. The furring strips were then nailed on and finished as nearly as possible as in No. 82. The plaster may have been a little thicker, as the panel was slightly heavier. As the amount of sound transmitted was also slightly less, the result indicated that this change in the method of fastening the furring strips did not appreciably affect the sound insulation of the panel.

This surface was then stripped and insulite used as the plaster base, as panel No. 84. With the exception of the change in plaster base, panels Nos. 83 and 84 were made as nearly the same as possible. The sound transmission was about the same, although panel No. 84 was lighter.

Comparison of the transmission of No. 73 with Nos. 71 and 72 apparently indicates that a plaster base of fiber board may give somewhat better sound insulation than metal lath, while No. 74, with a different type of fiber board, shows no improvement. This

- difference between Nos. 73 and 74 is probably not to be ascribed to the difference in the fiber boards. Panel No. 74 was built about a year after Nos. 71, 72, and 73 and of a different lot of tile. It is possible that this has affected the results. In any case, however, it is apparent that where a slight increase in weight is not objectionable there is little choice between the use of different plaster bases. The important part is the type of structure.

For structures which have wood studs or wood joists there has been very little progress made in improving the sound insulation. A comparison of the results shows that some of the earlier structures tested are as good sound insulators as the later ones.

\section{IMPACT OR TAPPING SOUNDS}

The preceding discussion has had reference entirely to air-borne sounds. Another type of sound, much harder to control, is produced by vibration communicated directly to the structure. This may be transferred from a machine or caused by impact, as when a chair is dropped or by walking across the floor. In many cases of this kind it seems as if the noise is as loud on one side of the floor or partition as on the other.

To study this type of sound, a special machine was built. (Fig. 4.) It consists, essentially, of five rods which can be raised and allowed to fall by separate cams. The cams are driven by a motor at such a speed that a rod falls approximately every fifth of a second. The 
B. S. Journal of Research, RP48

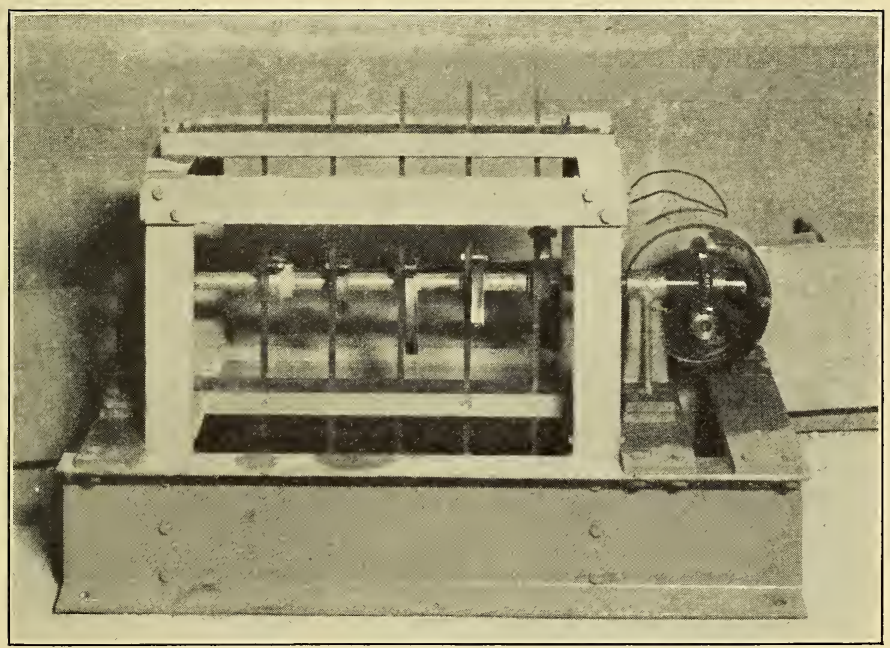

FIG. 4.-Machine for producing impact sounds 
noise thus produced can be measured in the same manner as the sound from a loud-speaker.

Measurements were taken of the intensity of the sound on both sides of the floor panel. The ratios of the results, expressed as reduction factors in sensation units, are recorded in the column headed "Tapping" in Table 1.

Two sets of these measurements are of special interest. Panel 116a, a type of concrete floor, shows a reduction of only 1.2 sensation unit in the intensity of sound on the two sides-almost indistinguishable by the ear. By adding a floating floor, loosely laid on the concrete (No. 116b), the reduction was increased to 30 sensation units, a noticeable change, but insufficient to prevent the transmission of footsteps. By the further addition of fiber board between the floor and the concrete (No. 116c) the reduction was increased to 33 sensation units, at which footsteps were still audible.

Similar results were obtained with panel No. 117a, which is a combination floor of 4-inch hollow clay partition tile. In its original condition this gives a reduction of 5.1 sensation units, which makes but little difference to the ear. By the addition of a floating floor (117b) the reduction was increased to 34 sensation units, and by the further insertion of fiber board (117c) to 35 sensation units. Even this latter figure was insufficient to deaden the sound of footsteps; but by the final addition of a suspended ceiling below (118) the reduction was raised to 51 sensation units, enough to prevent the sound of footsteps being transmitted under ordinary conditions.

\section{GENERAL CONCLUSIONS}

When comparing panels, it should be remembered that, owing to the form in which the results are expressed, the improvement of one panel over another should be expressed as a difference of their reduction factors in sensation units and not as a ratio. For instance, if one panel has a reduction factor of 40 sensation units and another of 50 the panel having a reduction factor of 50 will reduce a sound heard through it 10 sensation units more than the one having a reduction factor of 40 ; but it would not be proper to say that the better panel in this case is one-fourth, or 25 per cent, better than the poorer one. This can be illustrated as follows: Assume the original intensity of the sound as 60 sensation units. The intensity as heard through the best panel would be $60-50=10$ sensation units. As heard through the poorer panel it would $60-40=20$ sensation units. As heard under these conditions the best panel appears to be twice as good as the poorer one. Assume, now, the original intensity of the sound to be changed to 80 sensation units. As heard through the best panel the intensity would be 30 and through the poorer 40 . On this basis the best panel would appear to be only $4 / 3$ instead of twice as good as 
the poorer one. It is evident, then, that one panel can not be expressed as being a better sound insulator than another by a certain percentage. It will be noticed in both cases, however, that the sound which is heard through the poorer panel is 10 sensation units louder than that heard through the better panel. This holds, no matter what the original intensity of the sound (providing it is audible through the better panel), and is the only correct method of stating the improvement of one panel over another.

TABLE 1

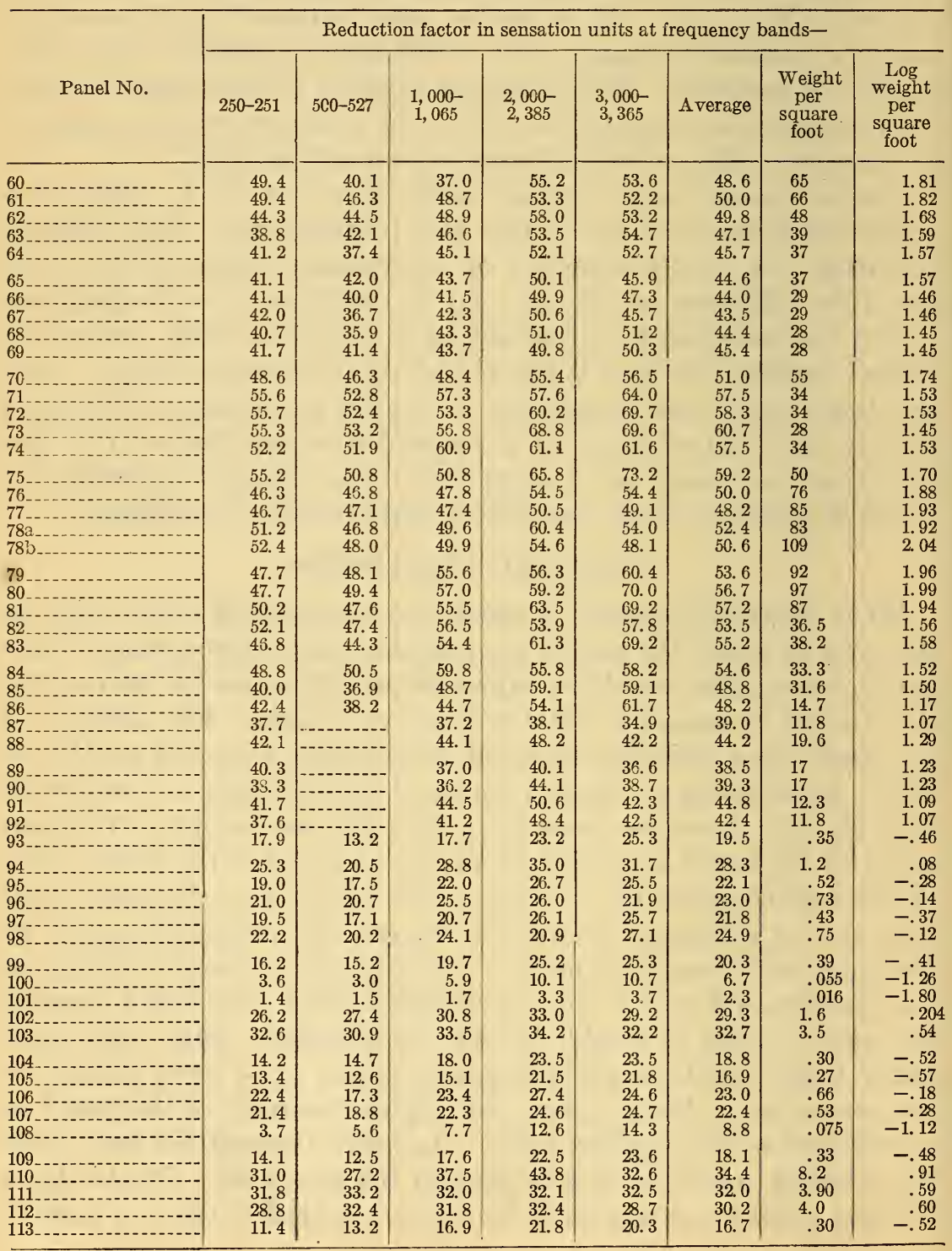


TABLE 1-Continued

\begin{tabular}{|c|c|c|c|c|c|c|c|c|c|c|}
\hline \multirow[b]{2}{*}{ Panel No. } & \multicolumn{10}{|c|}{ Reduction factor in sensation units at frequency bands- } \\
\hline & $150-187$ & $250-285$ & $500-547$ & $\begin{array}{r}1,000- \\
1,070\end{array}$ & $\begin{array}{c}2,000- \\
2,175\end{array}$ & $\begin{array}{r}3,000- \\
3,165\end{array}$ & $\begin{array}{l}\text { Aver- } \\
\text { age }\end{array}$ & $\begin{array}{l}\text { Weight } \\
\text { per } \\
\text { square } \\
\text { foot }\end{array}$ & $\begin{array}{l}\text { Log } \\
\text { weight } \\
\text { per } \\
\text { square } \\
\text { foot }\end{array}$ & $\begin{array}{l}\text { Tap- } \\
\text { ping }\end{array}$ \\
\hline $\begin{array}{l}114 \mathrm{a} . . . \\
114 \mathrm{~b} . .- \\
114 \mathrm{c}-.- \\
114 \mathrm{~d} . .- \\
115 \mathrm{a} . .-\end{array}$ & $\begin{array}{l}47.9 \\
47.7 \\
57.6 \\
57.9 \\
52.6\end{array}$ & $\begin{array}{l}46.8 \\
48.3 \\
57.5 \\
60.1 \\
53.6\end{array}$ & $\begin{array}{l}40.7 \\
40.6 \\
54.8 \\
53.5 \\
49.2\end{array}$ & $\begin{array}{l}50.1 \\
50.3 \\
62.4 \\
62.7 \\
54.9\end{array}$ & $\begin{array}{l}48.8 \\
48.9 \\
57.6 \\
55.7 \\
55.3\end{array}$ & $\begin{array}{l}47.4 \\
46.6 \\
56.6 \\
56.7 \\
55.0\end{array}$ & $\begin{array}{l}47.0 \\
47.1 \\
57.8 \\
57.8 \\
53.4\end{array}$ & 12.6 & 1.10 & $\begin{array}{l}14 \\
14 \\
22 \\
22 \\
22\end{array}$ \\
\hline $\begin{array}{l}115 \mathrm{~b}-.- \\
116 \mathrm{a}-. . \\
116 \mathrm{~b}-.- \\
116 \mathrm{c}-. . \\
117 \mathrm{a}_{-.-}\end{array}$ & $\begin{array}{l}62.4 \\
50.9 \\
58.9 \\
57.9 \\
56.5\end{array}$ & $\begin{array}{l}65.3 \\
54.8 \\
57.0 \\
58.2 \\
56.6\end{array}$ & $\begin{array}{l}57.3 \\
58.7 \\
55.4 \\
55.8 \\
55.8\end{array}$ & $\begin{array}{l}68.8 \\
56.5 \\
67.6 \\
66.3 \\
57.7\end{array}$ & $\begin{array}{l}62.3 \\
53.2 \\
65.2 \\
67.3 \\
58.8\end{array}$ & $\begin{array}{l}65.0 \\
56.0 \\
62.5 \\
62.3 \\
57.2\end{array}$ & $\begin{array}{l}63.5 \\
55.0 \\
61.1 \\
61.3 \\
57.1\end{array}$ & $\begin{array}{l}16.1 \\
54.4 \\
58.1 \\
58.9 \\
69.8\end{array}$ & $\begin{array}{l}1.21 \\
1.74 \\
1.76 \\
1.77 \\
1.84\end{array}$ & $\begin{array}{l}30 \\
1.2 \\
30 \\
33 \\
5.1\end{array}$ \\
\hline $\begin{array}{l}117 \mathrm{~b}-1-1 \\
117 \mathrm{c}-\mathrm{-} \\
118 \\
119\end{array}$ & $\begin{array}{l}62.7 \\
63.6 \\
68.0 \\
38.2 \\
28.5\end{array}$ & $\begin{array}{l}63.1 \\
70.3 \\
67.9 \\
39.6 \\
28.6\end{array}$ & $\begin{array}{l}61.0 \\
63.4 \\
65.8 \\
39.2 \\
24.0\end{array}$ & $\begin{array}{l}65.9 \\
63.5 \\
72.1 \\
43.9 \\
35.6\end{array}$ & $\begin{array}{r}73.7 \\
68.7 \\
<76.0 \\
49.0 \\
47.5\end{array}$ & $\begin{array}{r}67.4 \\
68.0 \\
<77.0 \\
58.8 \\
50.7\end{array}$ & $\begin{array}{r}65.6 \\
66.3 \\
<70.0 \\
44.8 \\
35.8\end{array}$ & $\begin{array}{c}73.5 \\
74.2 \\
72.8 \\
17.4 \\
5.10\end{array}$ & $\begin{array}{l}1.87 \\
1.87 \\
1.86 \\
1.24 \\
.71\end{array}$ & $\begin{array}{l}34 \\
35 \\
51 \\
-\end{array}$ \\
\hline $\begin{array}{l}121 \\
122 \\
124\end{array}$ & $\begin{array}{l}33.9 \\
50.2 \\
46.2 \\
34.1\end{array}$ & $\begin{array}{l}32.2 \\
52.2 \\
39.5 \\
29.9\end{array}$ & $\begin{array}{l}29.4 \\
43.9 \\
47.2 \\
27.9\end{array}$ & $\begin{array}{l}40.8 \\
57.9 \\
57.0 \\
41.8\end{array}$ & $\begin{array}{l}58.5 \\
61.0 \\
56.3 \\
59.3\end{array}$ & $\begin{array}{l}63.9 \\
61.1 \\
55.2 \\
60.1\end{array}$ & $\begin{array}{l}43.1 \\
54.4 \\
50.3 \\
42.2\end{array}$ & $\begin{array}{c}6.60 \\
14.2 \\
13.3 \\
4.94\end{array}$ & $\begin{array}{r}.82 \\
1.15 \\
1.12 \\
.69\end{array}$ & \\
\hline $\begin{array}{l}125 \\
126 \\
127 \\
128\end{array}$ & $\begin{array}{l}52.2 \\
50.1 \\
45.4 \\
49.9\end{array}$ & $\begin{array}{l}52.6 \\
52.2 \\
45.1 \\
53.0\end{array}$ & $\begin{array}{l}47.4 \\
49.4 \\
44.7 \\
52.0\end{array}$ & $\begin{array}{l}53.7 \\
59.6 \\
47.6 \\
57.3\end{array}$ & $\begin{array}{l}58.2 \\
60.1 \\
57.7 \\
62.9\end{array}$ & $\begin{array}{l}62.7 \\
53.8 \\
59.0 \\
66.2\end{array}$ & $\begin{array}{l}54.5 \\
54.2 \\
49.9 \\
56.9\end{array}$ & $\begin{array}{l}16.1 \\
13.1 \\
20.9 \\
21.3\end{array}$ & $\begin{array}{l}\text { 1. } 21 \\
\text { 1. } 12 \\
\text { 1. } 32 \\
\text { 1. } 33\end{array}$ & \\
\hline
\end{tabular}

The most important fact to know about a panel is not how much better it is than another but whether it will reduce a given sound to inaudibility. To determine this, two things should be known-the intensity of the sound which it is desired to reduce to inaudibility and the minimum intensity of the sounds present in the room where the listener is located. For instance, very slight noises in this room might mask any sound having an intensity of 20 or less sensation units. If the noise which we wish to reduce to inaudibility has an intensity of 70, the wall or partition should have a reduction factor of 50. This will reduce the sound to an intensity of $20 \mathrm{units}$, and this would be masked by the other noises present so as to be inaudible. If the room is absolutely quiet, it will be necessary to have a partition with a reduction factor of 70 to reduce the sound to inaudibility. Whether a partition is satisfactory or not depends, therefore, upon the intensity of other noises present. Street noises, for instance, may completely mask sounds having intensities of as much as 30 or more sensation units.

Panel

\section{DESCRIPTION OF PANELS}

60. Hollow clay tile panel ( 2 units $33 / 4$ by 12 by 12 and 8 by 12 by 12 ), end construction. Plastered both sides with brown coat of gypsum plaster and smooth white finish.

61. Hollow clay tile panel ( 2 units $33 / 4$ by 5 by 12 and 8 by 5 by 12), side construction. Plastered both sides with brown coast of gypsum plaster, smooth white finish. 
Panel

No.

62. Hollow clay tile panel constructed of 8 by 12 by 12 tile, 6 cells. Plastered on both sides with brown coat of gypsum plaster, smooth white finish.

63. Hollow clay tile panel constructed of 6 by 12 by 12 load-bearing partition tile, 6 cells. Plastered on both sides with brown coat of gypsum plaster, smooth white finish.

64. Hollow clay tile panel constructed of 6 by 12 by 12 partition tile, medium burned, 3 cells. Plastered both sides with brown coat of gypsum plaster and smooth white finish.

65. Hollow clay tile panel constructed of 6 by 12 by 12 soft partition tile, 3 cells. Plastered on both sides with brown coat of gypsum plaster, smooth white finish.

66. Hollow clay tile panel constructed of 4 by 12 by 12 partition tile, 3 cells. Plastered on both sides with brown coat of gypsum plaster, smooth white finish.

67. Hollow clay tile panel constructed of 4 by 12 by 12 partition tile, 3 cells. The tile in this panel was laid so that none of the flues in the panel were over 2 feet in length. Plastered both sides with brown coat of gypsum plaster, smooth white finish.

68. Hollow clay tile panel eonstructed of 3 by 12 by 12 partition tile, 3 cells. Plastered both sides with brown coat of gypsum plaster, smooth white finish.

69. Built as near like No. 68 as possible.

70. Hollow clay tile panel constructed of Heath cubes. Plastered both sides with brown coat of gypsum plaster, smooth white finish.

71. Hollow clay tile panel constructed of 4 by 12 by 12 partition tile, 3 cells. Wood furring strips, paper, metal lath, scratch and brown coat of gypsum plaster, smooth white finish.

72. Hollow clay tile panel constructed of 4 by 12 by 12 partition tile, 3 cells, pads, wood furring strips, paper, metal lath, scratch and brown coats of gypsum plaster, smooth white finish.

73. Hollow clay tile panel constructed of 4 by 12 by 12 partition tile, 3 cells, wood furring strips, Masonite, brown coat gypsum plaster, smooth white finish.

74. Hollow clay tile panel constructed of 4 by 12 by 12 partition tile, 3 cells, wood furring strips, Insulite, brown coat of gypsum plaster, smooth white finish.

75. Double partition 3 by 12 by 12 hollow clay tile spaced $13 / 4$ inches between sides. Flax-li-num 1 inch thick and butted tight was placed in the space between the tile. One side of the partition was carried on $1 / 2$-inch Flaxli-num strips which were 4 inches wide, the strips being placed at the sides and top as well as the bottom.

76. Flat arch floor panel constructed of 8-inch 4-cell tile, plastered with brown coat gypsum plaster and smooth white finish. Two by fours were fastened to the top surface approximately 16 inches on center and the space between filled with cinder concrete. The floor was finished with hardwood flooring.

77. Same as 76, except the floor was finished with 2 inches of cinder concrete and 1 inch cement.

78a. Combination floor panel constructed of 6 by 12 by 12, 3-cell partition tile. The ceiling of this panel was finished with a brown coat of gypsum plaster and a smooth white finish.

$78 \mathrm{~b}$. This panel was the same as 78a, except 2 inches of cinder concrete and 1 inch cement were added to upper surface. 
79. Eight-inch brick panel, New Hampshire brick, poor workmanship, plastered on both sides with brown coat gypsum plaster, smooth white finish.

80. Eight-inch brick panel, New Hampshire brick, good workmanship, plastered on both sides with brown coat gypsum plaster, smooth white finish.

81. Eight-inch brick panel, Mississippi brick, good workmanship, plastered on both sides with brown coat gypsum plaster, smooth white finish.

82. New Hampshire brick laid on edge, furring strips wired, gypsum plaster board, plastered both sides with scratch and brown coat gypsum plaster, smooth white finish.

83. Same as No. 82 , except the furring strips were nailed.

84. Same as No. 83, except Insulite was used as a plaster base instead of gypsum plaster board.

85. Same as No. 82, except the plaster was applied direetly to the brick surface.

86. Wood studs, $1 / 2$-inch Flax-li-num nailed to each side, 1 by 2 inch furring strips, wood lath, plastered both sides with scratch and brown gypsum plaster, smooth white finish.

87. Wood studs, Sheet Rock nailed to each side, No. 12 porous gypsum poured into space between studs.

88. Same as No. 87 , except No. 30 porous gypsum was used.

89. Same as No. 87, except No. 18 porous gypsum was used.

90. Same as No. 87, except No. 24 porous gypsum was used.

91. Wood studs, Sheet Rock nailed to one side and temporary form on the opposite side. No. 18 porous gypsum was poured in space between studs. After the porous gypsum set the form was removed and the gypsum allowed to dry. When dry, Sheet Rock was nailed on in place of form.

92. Same as No. 91 except Gypsolite was used in place of Sheet Rock and No. 12 porous gypsum in place of No. 18.

93. Single sheet of aluminum 0.025 inch thick.

94. Single sheet of galvanized iron 0.03 inch thick.

95. Single sheet 3 -ply plywood $1 / 8$ inch thick.

96. Single sheet 3 -ply plywood $1 / 4$ inch thick.

97. Single sheet Insulite $5 / 16$ inch thick.

98. Single sheet Insulite $1 / 2$ inch thick.

99. Single sheet Insulite $1 / 4$ inch thick.

100. Single sheet airplane fabric doped and varnished.

101. Single sheet heavy wrapping paper.

102. Single sheet double-strength glass $1 / 8$ inch thick.

103. Single sheet plate glass $1 / 4$ inch thick.

104. Single sheet standard Celotex $1 / 4$ inch thick.

105. Single sheet carpet lining Celotex $1 / 4$ inch thick.

106. Single sheet standard Celotex $1 / 2$ inch thick.

107. Single sheet carpet lining Celotex $1 / 2$ inch thick.

108. Single sheet aluminum 0.006 inch thick.

109. Single sheet duralumin 0.020 inch thick.

110. Single sheet of lead $1 / 8$ inch thick.

111. Single sheet of lead $1 / 16$ inch thick.

112. Single sheet galvanized iron 0.03 inch thick, loaded with 2.8 pounds sand per square foot.

113. Single sheet aluminum-coated duralumin.

114a. Floor panel, wood joists. Plaster on wood lath applied to lower side, subflooring and $3 / 8$-inch finish flooring to upper side.

114b. Same as No. 114a, with exception of flooring. One-half inch Insulite between rough and finished floors. 
Panel

No.

114c. Same as No. 114a, with exception of flooring. Rough flooring, $1 / 2$-inch Insulite, floating floor consisting of nailing strips rough and finish flooring.

114d. Same as No. 114c, except Insulite was inserted between rough and finished floor in floating floor.

115a. Suspended ceiling, wood joists, $1 / 2$-inch Insulite plastered applied as ceiling. Rough floor, finish floor applied as flooring.

115b. Same as $115 \mathrm{a}$, with exception of flooring. Rough flooring, $1 / 2$-inch Insulite and floating floor as in 114c.

116a. Reinforced concrete flat slab type of floor construction. Insulite furred out and applied as ceiling, plaster.

116b. Same as 116a except floating floor added as in 114c.

116c. Same as $116 \mathrm{~b}$, except $1 / 2$-inch Insulite added between concrete slab and floating floor.

117a. Combination floor panel constructed of 4 by 12 by 12 three-cell partition tile. The ceiling was finished with furring strips, $1 / 2$-inch Insulite, and plaster.

117b. Same as 117a, except floating floor was added as in 114c.

117c. Same as $117 \mathrm{~b}$, except $1 / 2$-inch Insulite was added between masonry slab and floating floor.

118. Same as $117 \mathrm{c}$, except ceiling was stripped off and suspended ceiling attached.

119. Wood studs, wood lath, scratch and brown coats gypsum plaster, smooth white finish.

120. Wood studs, $1 / 2$-inch Insulite applied to both sides, joints filled.

121. Wood studs, two $1 / 2$-inch sheets of Insulite applied to both sides, joints filled.

122. Same as No. 121, with addition of scratch and brown coats gypsum plaster, smooth white finish.

123. Same as No. 120, with addition of scratch and brown coats gypsum plaster, smooth white finish.

124. Staggered wood studs, $1 / 2$-inch Insulite applied to both sides, joints filled.

125. Same as No. 124, with addition of Ecod Fabric, scratch and brown coats gypsum plaster, smooth white finish.

126. Same as No. 124 with addition of scratch and brown coats gypsum plaster, smooth white finish.

127. Wood studs, $1 / 2$-inch Insulite applied to one side, plastered and back plastered. Metal lath applied to opposite side and plastered with scratch, brown, and finish coats.

128. Wood studs, $1 / 2$-inch Insulite applied to one side, plastered with brown coat and back plastered, furring strips, 1/2-inch Insulite, scratch, brown, and finish coats gypsum plaster. The opposite side was covered with metal lath plastered with scratch, brown, and finish coats gypsum plaster.

\section{GENERAL SPECIFICATIONS FOR CONSTRUCTION OF TEST PANELS}

1. ERECTION of Brick.-The brick were laid in mortar composed of 1 part Portland cement, 1/10 part mason's hydrated lime, and 3 parts sand by volume. The surfaces to be plastered were reasonably true and free from dirt or other loose material. The joints were flush with the surface.

2. Erection of Clay Tile.-Unless otherwise specified, the tile were medium burned hollow clay tile and laid in a mortar composed 
of 1 part Portland cement, 1 part mason's hydrated lime, and 4 parts sand by volume. The surfaces to be plastered were reasonably true and free from dirt or other loose material. The joints were flush with the surface.

3. Erection of Reinforced Concrete Slab.-The concrete used in the slab was composed of 1 part Portland cement, 2 parts concrete sand, and 4 parts gravel by volume. The slab was 4 inches thick and reinforced with $3 / 8$ inch round deformed rods placed 9 inches on center. Furring strips were applied to one side before the concrete set, nails previously driven through the furring strips being used as a tie.

4. Erection of Combination Floor Slabs.-The concrete mix was the same as in paragraph 3 . The rows of tile were spaced about 18 inches on center. The space between the tile was filled with concrete and about 2 inches of concrete was poured on top. In panel 117 a each concrete joist was reinforced by two $3 / 8$ inch round rods.

5. Erection of Wood Studs.-(a) Straight studding.-New straight 2 by 4 's were used. They were spaced 16 inches on center and securely nailed to the frame, which consisted of 3 by 4's.

(b) Staggered studding. - New straight 2 by 4's were used. They were spaced 8 inches on centers, alternate studs having a 2-inch projection. The studs were securely nailed to the cap and base, each of which consisted of a 2 by 6 .

6. Erection of Wood Joist.-(a) New straight 2 by 4's were used. They were spaced 16 inches on centers and securely nailed to a frame which consisted of 3 by 4's.

(b) Joists for suspended ceiling.-New straight 2 by 4's were used. The floor joists were spaced so that each one was 4 inches to the right from the centers of a floor joist, and the bottom was 2 inches lower than the bottom of the floor joist.

7. Erection of Wood Lath.-Four-foot laths were used, straight and free from knots. The laths were erected on both sides of the panel, parallel to each other, three-eighths of an inch apart and perpendicular to the direction of the studs. They were cut to such lengths that both ends of each lath came over a support. The end joints between laths were staggered at every seventh lath." Each lath was nailed to each support it crossed. The laths were wetted the day before the scratch coat was applied.

8. Erection of Metal Lath.-This was expanded metal lath, painted, and of medium weight. The sheets were attached with their longer dimensions across the supports. A sheet of lath being 8 feet long, there were no joints between ends. The joints between the sides of the sheets were lapped one full mesh and tied with No. 18 iron wire midway between supports. Each sheet was securely fas- 
tened to each support it crossed, the fastenings being spaced about 6 inches apart across the width of the sheet.

9. Erection of Ecod Fabric.-Each sheet was securely fastened to every support it crossed, the fastenings being spaced about 6 inches apart along the studs. All end joints were made over a stud. The side joints were lapped one full mesh.

10. Erection of Insulite. - The insulite used was cut from 4 by 12 -foot by $1 / 2$-inch stock to sizes required for the panels. Each $1 / 2$-inch layer was nailed to each joist, stud, or furring strip, as the case happened to be, with fourpenny nails approximately 6 inches apart. One-quarter inch joints were allowed between sheets of insulite. Wire mesh was applied over joints on panels to be plastered. On panels which were not plastered the joints were filled.

11. Erection of Masonite.-This was erected in the same manner as insulite, paragraph 10.

12. Erection of Gypsum Plaster Board.-These boards were 32 by 36 by $3 / 8$ inch. Both sides of the panel were covered with these boards, erected so that the 36 -inch dimension ran parallel to the furring strips. The boards were cut so that the sides of each board came over the furring strips. The joints were staggered every row. A space of $1 / 4$ inch was left all around each board. Both sides and the center of each board were nailed to the furring strips every 6 inches.

13. ERection of FlaX-Li-Num.-The Flax-li-num was erected according to manufacturers' specifications.

14. Erection of Furring Strips.-The furring strips were of wood $13 / 16$ inch by 2 inches by 7 feet 2 inches. These strips were either wired or nailed to the panels 16 inches on centers.

15. Scratch Coat Gypsum Plaster.- - This coat was composed of 1 part retarded neat gypsum plaster and 2 parts dry sand by weight. The ingredients were thoroughly mixed, first dry and again wet. The exposed surface was reasonably true and was scratched with an appropriate tool. The thickness of this coat was approximately $1 / 4$ inch.

16. Brown Coat Gypsum Plaster.-This coat was composed of 1 part retarded neat gypsum plaster to 3 parts dry sand by weight. The ingredients were thoroughly mixed, first dry and again wet, and applied with sufficient pressure to form a good bond. When the plaster base was masonry, insulite, masonite, or gypsum plaster board, this coat was built out until the average thickness of the plaster was $1 / 2$ inch, rodded and floated to a true, even surface. For wood and metal lath the total thickness of the plaster from the face of the studs or furring strips to the face of the plaster was $7 / 8$ inch.

17. Sмоотн Finish Coat.-This coat was composed of one bag of finishing hydrated lime to one-half bag of unretarded gypsum plaster. The lime was made into a putty with water at least 24 hours prior to 
use. A small amount of this putty. was circled out on the plasterer's board, some water put into the circle, and gauging plaster equal to one-half the volume of the putty dusted into the water. The whole was then mixed with a trowel, more water being added if necessary. More material was not mixed at one time than could be used in 30 minutes. The mixture was not retempered, but each batch was started with clean board and tools. This plaster was applied as a thin, even layer over the brown coat. It was watched carefully for the appearance of incipient crystallization. When this occurred, it was immediately troweled down to a smooth, true finish, using considerable pressure on the trowel, and brushing the surface with water if necessary. This coat was as thin as possbile without permitting the brown coat to show through.

18. Erection of Subflooring.-New, straight $3 / 4$ by $31 / 2$ inch stock was used. It was applied diagonally across the floor joists and well nailed.

19. Erection Finish Flooring.-New, straight $3 / 8$-inch oak stock was used, except for panel No. 76. The oak flooring was applied perpendicular to the joist and securely nailed. For panel No. 76, $3 / 4$-inch maple flooring was used and nailed directly to nailing strips without the use of rough flooring.

20. Erection of Floating Floor. - This was made of 1 by 2 inch nailing strips, subflooring nailed at right angles to the nailing strips, and finished flooring nailed at right angles to subflooring.

21. Erection of Suspended Ceiling.-This was made up on a wood frame. Screw eyes were inserted so that it could be suspended with wires from the masonry floor. Insulite was used as a plaster base, and this was plastered in the usual way.

22. Cinder Fill.-This was composed of one bag of Portland cement to 10 cubic feet of cinders. These ingredients were thoroughly mixed, first dry and again wet, then tamped into place on the floor.

23. Concrete Finish on Floors.-This was composed of one bag of Portland cement to 3 cubic feet of dry sand. This was thoroughly mixed and poured over the cinder concrete so as to have an average thickness of 1 inch. The surface was troweled off to give a smooth, level finish.

Washington, October 25, 1928. 